AperTO - Archivio Istituzionale Open Access dell'Università di Torino

\title{
Prioritisation of health research.
}

\section{This is the author's manuscript}

Original Citation:

Availability:

This version is available http://hdl.handle.net/2318/142593

since 2016-11-04T11:57:51Z

Published version:

DOI:10.1016/S0140-6736(10)61248-2

Terms of use:

Open Access

Anyone can freely access the full text of works made available as "Open Access". Works made available under a Creative Commons license can be used according to the terms and conditions of said license. Use of all other works requires consent of the right holder (author or publisher) if not exempted from copyright protection by the applicable law. 
This Accepted Author Manuscript (AAM) is copyrighted and published by Elsevier. It is posted here by agreement between Elsevier and the University of Turin. Changes resulting from the publishing process - such as editing, corrections, structural formatting, and other quality control mechanisms - may not be reflected in this version of the text. The definitive version of the text was subsequently published in THE LANCET, 376, 2010, $10.1016 / \mathrm{S} 0140-6736(10) 61248-2$.

You may download, copy and otherwise use the AAM for non-commercial purposes provided that your license is limited by the following restrictions:

(1) You may use this AAM for non-commercial purposes only under the terms of the CC-BY-NC-ND license.

(2) The integrity of the work and identification of the author, copyright owner, and publisher must be preserved in any copy.

(3) You must attribute this AAM in the following format: Creative Commons BY-NC-ND license (http://creativecommons.org/licenses/by-nc-nd/4.0/deed.en), $10.1016 / \mathrm{S} 0140-6736(10) 61248-2$

The publisher's version is available at:

http://linkinghub.elsevier.com/retrieve/pii/S0140673610612482

When citing, please refer to the published version.

Link to this full text:

http://hdl.handle.net/2318/142593 


\section{Prioritisation of health research}

Savino Sciascia ${ }^{\mathrm{a}}$, Gurmeen Kaur ${ }^{\mathrm{b}}$, Elias Melhem ${ }^{\mathrm{c}}$, Sahin Khaniyev ${ }^{\mathrm{d}}$, Abdrahamane Ouedraogo ${ }^{\mathrm{e}}$, Simukai Chigudu ${ }^{\mathrm{f}}$, on behalf of The Lancet Student Team and all Regional Advisors

a University of Turin, 10100 Turin, Italy

${ }^{\mathrm{b}}$ University of Delhi, Delhi, India

${ }^{c}$ Université Saint-Joseph, Beirut, Lebanon

${ }^{\mathrm{d}}$ Hacettepe University Sihhiye, Ankara, Turkey

${ }^{\mathrm{e}}$ Université de Ouagadougou, Ouagadougou, Burkina Faso

${ }^{\mathrm{f}}$ University of Newcastle, Newcastle, UK

In response to the Comment "Young Voices demand health research goals", ${ }^{1}$ we would like to offer our experiences as The Lancet Student Regional Advisor Group and representatives

of TheLancetStudent.com (TLS).

TLS aims to encourage students everywhere to engage in global health and research activities. As students, we are concerned that the voices of young people worldwide remain unheard when it comes to health research. TLS groups and Regional Advisors (students themselves) are working hard to promote interdisciplinary collaboration between students and researchers, and trying to close the gap between universities, health institutes, global partners, and policy makers. We are aware that talented young researchers from developing countries have fewer opportunities to submit research proposals. Our experience from TLS groups in such countries makes us believe that, with guidance and training in health promotion and in research, students can add value and we believe that our enthusiasm and ideas can empower and influence health-care policies.

Through our worldwide collaboration with young people, we know that students themselves want to be more involved in global health issues. We try to do our part by informing, raising awareness, and, most importantly, encouraging students to get involved in global health and research and overcome major challenges in health research:2bridging the gap between the young researchers and policy makers to produce worldwide high-quality research focused on communities' needs.

\section{References}

1 Kok M, de Souza DK. Young Voices demand health research goals. Lancet 2010; 375: 1416-17.

2 Anon. Declaration of the International Students' Meeting on Public Health (ISMOPH). April 27, 2009; Istanbul,Turkey. http://www.t-hasak.org/ english/word\%20congres/ismoph.pdf (accessed July 27, 2010). 